\title{
Member of High Risk Population
}

National Cancer Institute

\section{Source}

National Cancer Institute. Member of High Risk Population. NCI Thesaurus. Code C102666.

An indication that a person is part of a population group that has a greater chance of contracting a disease or disorder. 